Cramp S. \& Simmons K.E.L. (eds), 1983 - The Birds of the Western Palearctic, vol. IV - Oxford University Press, Oxford.

Fracasso G., Mezzavilla F. \& Scarton F., 2001 - Check-List degli uccelli del Veneto (Ottobre 2000). In: Bon M. \& SCARTon F. (red.), 2001 - Atti del $3^{\circ}$ Convegno Faunisti Veneti. Associazione Faunisti Veneti - Boll. Mus. civ. St. Nat. Venezia, 51 (suppl.): 1-256.

Giovacchini P., CoRsi F. \& MANFRedA V., 2004 - Analisi e rassegna aggiornata delle osservazioni di Cuculo dal ciuffo Clamator glandarius nella Maremma grossetana - Alula, 11: 98-104.

Spina F. \& Volponi S., 2008 - Atlante della Migrazione degli Uccelli in Italia. 1. nonPasseriformi - Ministero dell'Ambiente e della Tutela del Territorio e del Mare, Istituto Superiore per la Protezione e la Ricerca Ambientale (ISPRA), Roma.

Stival E. \& SGorlon G., in stampa - Frequenza di osservazione delle specie ornitiche in provincia di Venezia. Dati preliminari 1983-2009 - Atti del VI Convegno dei Faunisti Veneti. Treviso, 15-16 maggio 2010.

Via C.A. Marcuzzo, 21/09 - I-31046 Faè di Oderzo TV E-mail: giacomo.sgorlon@email.it

\title{
XVI Convegno Italiano di Ornitologia
}

Il XVI Convegno Italiano di Ornitologia, organizzato da AsOER - Associazione Ornitologi dell'Emilia-Romagna ONLUS, si terrà a Cervia (RA), presso il Centro Congressi di Milano Marittima dal 22 al 25 settembre 2011.

Il convegno si svilupperà in tre giornate di incontri scientifici e una giornata di escursioni, organizzate in località di rilevante interesse naturalistico della Romagna.

I temi scelti per le sessioni sono: Ecologia; Comportamento; Migrazione; Dal monitoraggio alla gestione dell'avifauna nelle aree protette; Monitoraggio e conservazione dell'avifauna nei parchi e nei Siti di rete Natura 2000; Gli Studi ornitologici per la gestione delle popolazioni e degli ambienti; Risultati e prospettive dei progetti di monitoraggio a scala nazionale; Avifauna e caccia; Il ruolo dei CRAS nella conservazione dell'avifauna; Conservazione dell'avifauna in ambiente urbano.

Le tavole rotonde proposte sono: Il programma EURAPMON per il monitoraggio delle popolazioni di rapaci in Europa; Conservazione e monitoraggio del Fratino in Italia - attività svolte nel 2010-2011; Ornitho.it. Il termine ultimo per l'invio dei lavori è il 30 aprile 2011.

Informazioni, aggiornamenti del programma scientifico, formulario per l'invio dei contributi, scheda d'iscrizione e maggiori dettagli sul sito dell'AsOER: www.asoer.org 


\section{ISTRUZIONI PER GLI AUTORI}

La Rivista Italiana di Ornitologia pubblica articoli e note scientifici e recensioni originali. I lavori non possono essere presentati contemporaneamente ad altre riviste. È preferibile l'uso delle lingue italiana e inglese. I dattiloscritti vanno inviati in duplice copia a:

\section{Redazione Rivista Italiana di Ornitologia}

c/o Museo Civico di Storia Naturale - Corso Venezia 55 - 20121 Milano

Contestualmente alle copie cartacee deve pervenire in Redazione la copia digitale in formato IBM e programma di scrittura MSWord per Windows all'indirizzo e-mail:

\section{redazionerio@libero.it}

o su dischetto da 3,5 pollici o CD-rom, a mezzo posta.

Nella lettera di accompagnamento indicare l'indirizzo, il numero di telefono e l'e-mail dell'Autore cui fare riferimento per le successive comunicazioni. L'Autore trattenga copia digitale e cartacea del lavoro.

Si raccomanda la massima concisione. Ci si limiti, di regola, a pubblicare le notizie nuove.

\section{Norme redazionali}

Formato - I dattiloscritti devono essere predisposti per la stampa nella loro versione completa e definitiva, scritti in carattere "Times", corpo 10 pt con interlinea doppia. La copia cartacea deve essere stampata su un sola facciata del foglio formato A4 con margine bianco destro di almeno $5 \mathrm{~cm}$ di larghezza.

Figure e tabelle - Grafici, disegni e fotografie (contrassegnati con numerazione araba e denominati figure) e tabelle (contrassegnate con numerazione romana) devono pervenire con il dattiloscritto in fogli separati, indicando la loro posizione nel testo. Le loro dimensioni definitive non possono superare il formato $125 \times 190 \mathrm{~mm}$. Gli autori sono pregati di tener presente, nelle figure, la riduzione a cui le medesime verranno sottoposte nella stampa: sono da evitare segni troppo appressati o minuti, caratteri molto piccoli e punteggiatura o tratteggi chiari.

Organizzazione del testo - È preferibile che i contenuti dei lavori siano ordinati secondo il seguente schema: Autori; titolo; riassunto; parole chiave (massimo 5); abstract; key words (massimo 5); indirizzi (in calce); introduzione; area di studio, materiali e metodi; risultati; discussione; ringraziamenti; bibliografia. Il riassunto e l'abstract (comprensivo della traduzione del titolo) devono contenere l'informazione concisa dei risultati ottenuti e, se necessario, dei metodi di ricerca utilizzati. Nelle "Brevi Note" Autore e indirizzo vanno al termine della Nota.

Bibliografia - Le citazioni bibliografiche nel testo devono riportare il solo cognome dell'Autore/i in carattere MAIUSCOLO/MAIUSCOLETTO, seguito dall'anno di pubblicazione. Per esempio: (ARRIGONI DEGLI Oddi, 1929); (MolToni \& Di CARLo, 1970); (BRICHETTI et alii, 1992). Quando il nome dell'Autore/i è parte della frase, si proceda come da esempio: “... secondo ARRIGONI DEGLI ODDI (1929) ...”. La bibliografia deve comprendere esclusivamente le fonti citate nel testo e includere preferibilmente solo lavori pubblicati. I riferimenti si conformeranno ai seguenti standard:

articoli: $\quad$ Moltoni E. \& Di CARLo E.A., 1970 - Gli uccelli dell'isola d'Elba (Toscana) Riv. ital. Orn., 40: 285-388.

atti di convegni: ZBINDEN N., 1999 - Monitoraggio delle specie diffuse di uccelli nidificanti in Svizzera. In: Scarton F., Fracasso G. \& Bogliani G. (a cura di). Atti X Convegno Italiano Ornitologia - Avocetta, 23: 152.

volumi: $\quad$ ARRIGONI DEGLI ODd E., 1929 - Ornitologia italiana - Hoepli, Milano.

capitoli: $\quad$ Massa B., 1992 - Grillaio Falco naumanni. In: Brichetti P., De Franceschi P. \& BACCETTI N. (a cura di). Fauna d'Italia, XXIX, Aves. I - Calderini, Bologna, pp. 633-638.

\section{Altre norme}

I contributi saranno sottoposti al parere di Referee; il giudizio finale di accettazione spetta alla Redazione. I dattiloscritti, le figure e i dischetti non saranno restituiti.

Le bozze di stampa inviate agli Autori dovranno essere restituite corrette entro otto giorni; in caso contrario provvederà la Redazione. Delle "Brevi note" e delle "Recensioni" non sono inviate bozze.

Saranno inviati gratuitamente all'Autore corrispondente 50 estratti senza copertina per "Articolo". Estratti addizionali saranno fatturati a prezzo di costo. Non vengono stampati estratti delle "Brevi note" e delle "Recensioni".

Ai Soci della Società italiana di Scienze naturali sono concesse gratuitamente 8 pagine per volume, non cumulabili per articoli fatti in collaborazione tra più Soci. Le pagine eccedenti le gratuite sono a carico dell'Autore/i a $€ 30$ cadauna e saranno fatturate. In tal caso, allegati al dattiloscritto, vanno specificati gli estremi fiscali (nome, indirizzo e codice fiscale/partita I.V.A.) dell'intestatario della relativa fattura. Dette condizioni sono soggette a modifiche in rapporto alle variazioni dei costi di stampa. 


\section{NOTICE TO CONTRIBUTORS}

The Rivista Italiana di Ornitologia publishes original scientific articles and short notes. Papers must not be submitted to other scientific journals until negative response from the editorial board. Papers should be preferably written in Italian or in English. The manuscript must be mailed in two paper copies to:

\section{Redazione Rivista Italiana di Ornitologia}

c/o Museo Civico di Storia Naturale, Corso Venezia 55 I-20121 Milano

An IBM formatted file of the manuscript (Windows MSWord) must also be enclosed (3.5' diskette or CD-rom) or attached to an e-mail message addressed to:

\section{redazionerio@libero.it}

Please, clearly specify name, mailing and e-mail addresses and telephone number of the corresponding Author in the covering letter.

\section{Editorial instructions}

Format - The manuscript must be submitted to the editor in its complete and final version, "Times" type, point size 12, double spacing. Use A4 paper for printing and leave a blank margin of at least $5 \mathrm{~cm}$ on the right side of each page.

Figures and Tables - Use Arab numerals for Figures (graphs, drawings and photographs) and Roman numerals for Tables. Each Figure and Table must be printed on separate pages indicating their position in the text. They must not exceed 125x190 mm in size. Captions must be written in Italian and in English.

Organization of the text - Contents should preferably follow this scheme: Author(s), Address(es), Title, Abstract, Key words (maximum 5), Introduction, Study area, Materials and methods, Results, Discussion, Acknowledgements, References. The Abstract must inform concisely of the results obtained and, if necessary, of the research methods used.

References - Citations appearing in the text must quote the Author(s) surname(s) (CAPITALS/SMALL CAPITALS) followed by the publication year. For example: (ARRIGONI DEGLI ODDI, 1929); (MolTONI \& Di CARLO, 1970); (BRICHETTI et alii, 1992). When the Author surname is part of a sentence use this arrangement: “... according to ARRIGONI DEGLI ODDI (1929) ...". In the References chapter list only works cited in the text: if possible, avoid to quote unpublished material. References must conform to the following examples:

Journals Moltoni E. \& Di CARLO E.A., 1970 - Gli uccelli dell'isola d'Elba (Toscana) Riv. ital. Orn., 40: 285-388.

Proceedings ZBINDEN N., 1999 - Monitoraggio delle specie diffuse di uccelli nidificanti in Svizzera. In: Scarton F., Fracasso G. \& Bogliani G. (editors). Atti X Convegno Italiano Ornitologia - Avocetta, 23: 152.

Books ARRIGONI DEGLI ODd E., 1929 - Ornitologia italiana - Hoepli, Milano.

Chapters Massa B., 1992 - Grillaio Falco naumanni. In: BRichetti P., De Franceschi P. \& BACCETTI N. (editors). Fauna d'Italia, XXIX, Aves. I - Calderini, Bologna, pp. 633-638.

\section{Other instructions}

All manuscripts will be submitted to peer reviewers (referees); final acceptance will be issued by the Editors. Manuscripts, figures and floppy disks will not be returned to the Author(s).

Proofs mailed to the corresponding Author must be returned with revisions to the Editor within 8 days. Delay will result in corrections made by the Editor. The Editor will take charge for revisions on proofs of "Short notes" and "Reviews".

The corresponding Author will be presented with 50 reprints for each article. Additional reprints will be charged at cost price. No reprints of "Short notes" and "Reviews" will be produced.

Members of the Società Italiana di Scienze Naturali will benefit of 8 free printed pages/volume for publication of their works. Free pages are not cumulable among Members. Authors will be charged Euro 30/page if exceeding the 8 pages benefit. In this case, please specify whom the invoice should be addressed to. 